\title{
Diversity and stability of an estuarine trophic network
}

\author{
Jérémy Lobry ${ }^{1, *}$, Valérie David ${ }^{2}$, Stéphanie Pasquaud ${ }^{3}$, Mario Lepage ${ }^{3}$, \\ Benoît Sautour ${ }^{2}$, Eric Rochard ${ }^{3}$ \\ ${ }^{1}$ Ifremer, Centre de Nantes, Département EMH, Rue de l'Ile d'Yeu, BP 21105, 44311 Nantes Cedex 3, France \\ ${ }^{2}$ Laboratoire d'Océanographie Biologique, UMR 5805 Université Bordeaux I - CNRS, 2 rue du Professeur Jolyet, \\ 33120 Arcachon, France \\ ${ }^{3}$ Cemagref, Groupement de Bordeaux, Unité Ecosystèmes estuariens et poissons migrateurs amphihalins, \\ 50 avenue de Verdun, 33612 Cestas, France
}

\begin{abstract}
Estuarine areas provide highly valuable ecosystem benefits for human populations, despite being under intense demographic, economic and ecological pressures. Hence, an understanding of the structure and function of estuarine ecosystems is essential for understanding the persistence and stability of these ecosystems and their response to perturbations. This study synthesises available data and knowledge about the Gironde estuary (SW France) in a mass-balanced trophic model to illustrate potential key patterns in the functioning of the estuarine ecosystem and key elements of its stability. In order to evaluate the total direct and indirect impact on the whole community of the 2 main sources of anthropogenic perturbations in the estuarine area, mortalities induced by fishing and the Blayais nuclear power plant were included in the model. The results suggest that in the Gironde, a typical heterotrophic estuary, there is an asymmetrical flow between distinct and complementary energy channels that enhances the stability of the food web. This dynamic process is illustrated by differential trophic flows in the water column according to the seasons. The succession of species in the environment indicates an optimisation of the use of the available carbon resources over a typical year by the estuarine biological communities. Finally, it seems that an increase in human impacts could significantly affect the topology and functioning of the food web by altering stabilizing elements of the network and decreasing the diversity of trophic flows that insures resilience of the trophic structure.
\end{abstract}

KEY WORDS: Estuarine ecosystem $\cdot$ Food web $\cdot$ Network analysis $\cdot$ Stability $\cdot$ Diversity $\cdot$ Ecopath Gironde estuary

\section{INTRODUCTION}

Recent scientific controversies on implementing the 2000 European Water Framework Directive (EU 2000) in coastal and estuarine areas have highlighted the existence of an Estuarine Quality Paradox (Dauvin 2007, Elliott \& Quintino 2007). This paradox puts forward that because estuarine biological communities are well-adapted to cope with high natural and anthropogenic stress (and so may be regarded as resilient), it is difficult to quantify the effects of anthropogenic stress (Elliott \& Quintino 2007). Elliott \& Quintino (2007) discussed the difficulties of detecting anthropogenic change against a background of normal change in estuaries. Moreover, in the past, human-induced impacts on the biological communities of large estuaries were largely studied by considering the ecological compartments independently. Considering that functional properties may be more robust than structural ones (de Jonge et al. 2006), scientists are now consid- 
ering the ecosystem as a whole by defining reference patterns of ecosystem structure and function (Livingston 2002). The main ecological question becomes: 'How do environmental conditions, human-induced stress and spatial heterogeneity, which are all particularly limiting for biological communities, affect the organisation and functioning of estuarine ecosystems?' More precisely, we need to understand how the diversity in these ecosystems is related to their stability ${ }^{\mathbf{1}}$, persistence $^{2}$ and resilience ${ }^{3}$ (Ulanowicz 2003). In the field of coastal and estuarine studies, few works have focused on such an ecosystem approach (e.g. Baird et al. 1991, Baird \& Ulanowicz 1993, Wilson \& Parkes 1998, Livingston 2002, Rybarczyk \& Elkaim 2003, Rybarczyk et al. 2003).

This study is a first attempt to deal with the Estuarine Quality Paradox concept at the ecosystem level by considering a topological approach to the food web of one representative estuarine system, the Gironde estuary (SW France). This area is probably the largest estuary in Western Europe (Lobry et al. 2003) and is one of the least-polluted North European estuaries (Sautour \& Castel 1995), although several of the main anthropogenic pressures typical in estuarine environments are present, such as metallic and organic contamination, commercial fisheries and industrial activities. The Gironde estuary is also characterised by high turbidity, which limits primary production (Irigoien \& Castel 1997), and is considered a highly heterotrophic system (Goosen et al. 1999). Previous studies focused on different biological compartments: phytoplankton (Lemaire et al. 2002), zooplankton (Castel 1993, David et al. 2005, David et al. 2006), benthos (Bachelet et al. 1981), shrimps and fish (Lobry et al. 2003, Lobry et al. 2006); but ecological knowledge of these ecosystem compartments is still poorly documented. The main aim of this study is to investigate, in a comprehensive, integrated way, key patterns in the functioning of the estuarine ecosystem that contribute to its stability. We do this by taking into account: (1) trophic interactions using an Ecopath model (Polovina 1984, Christensen \& Pauly 1992); (2) dynamics of biological communities through a particular focus on the seasonal patterns of several biological compartments previously described in the Gironde estuary (Lobry et al. 2006, David et al. 2007); (3) interactions with coastal and riverine systems; and (4) 2 types of direct human impacts on estuarine populations - namely fisheries, and industrial abstraction and discharges.

${ }^{1}$ Capacity to remain within a nominal range of behaviours

$\underline{2}$ Ability to continue in existence with the same complement of species and flows

$\underline{3}$ If perturbed, the rate at which the systems return to their unperturbed status

\section{MATERIALS AND METHODS}

Study site. The Gironde estuary is located in SW France (Fig. 1). Its surface area is approximately $625 \mathrm{~km}^{2}$ at high tide. It is $76 \mathrm{~km}$ long between the ocean and the Bec d'Ambès, where the Dordogne and Garonne rivers meet, and which also constitutes the upstream salinity limit. The watershed covers $81000 \mathrm{~km}^{2}$ and the mean annual rate of freshwater discharge is around $1000 \mathrm{~m}^{3} \mathrm{~s}^{-1}$ (Sottolichio \& Castaing 1999). All these measurements make it the biggest estuary in France and the largest in Western Europe (Lobry et al. 2003). Annually, river systems carry between 1.5 and $3 \times 10^{6} \mathrm{t}$ of suspended sediment to the estuary (David et al. 2005). A permanent turbidity maximum zone exists, with suspended matter concentrations of about $1 \mathrm{~g} \mathrm{l}^{-1}$ at the surface and $10 \mathrm{~g} \mathrm{l}^{-1}$ near the bed (Sottolichio \& Castaing 1999). The Gironde is one of the most turbid estuaries in Europe, with yearly mean suspended particulate matter concentrations of $>500 \mathrm{mg} \mathrm{l}^{-1}$ (Sautour \& Castel 1995). As a consequence, primary production in the Gironde is reduced (10 $\mathrm{g} \mathrm{C} \mathrm{m}^{-2} \mathrm{yr}^{-1}$, Irigoien and Castel 1997).

The basin has a pluvio-nival hydrological regime with high discharge periods in autumn (rain) and spring (snowmelt) and low discharge in late summer. Temperature, salinity and river flow values in the estuary thus exhibit a clear seasonality with low values of water flow in summer (July to September) and high values of temperature and salinity during this period.

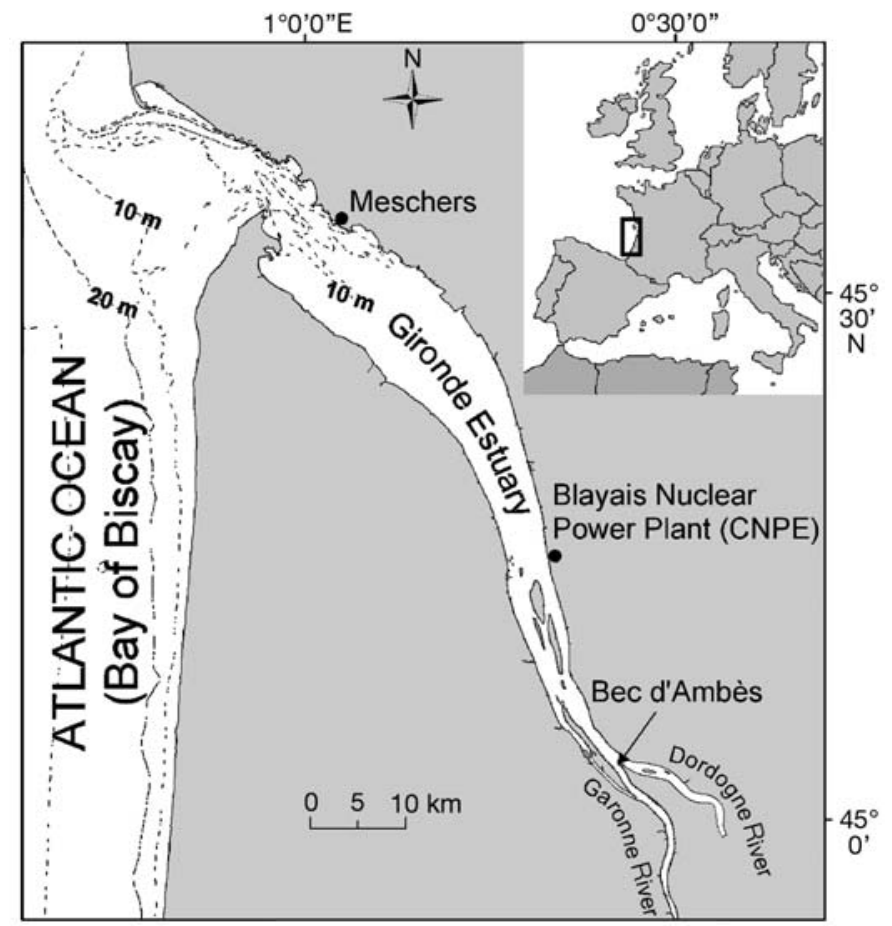

Fig. 1. Gironde estuary 
Ecopath modeling. Basis and data requirement: By using a mass balance, the Ecopath model (Polovina 1984, Christensen \& Pauly 1992) quantifies the trophic flows in an ecosystem (i.e. a food web in a study area). The parameterisation of the Ecopath model is based on satisfying 2 'master' equations. The first describes the production term for each compartment (ecological group) included in the system:

Production $=$ fishery catch + predation mortality + net migration + biomass accumulation + other mortality

The 'other mortality' term includes natural mortality factors such as mortality due to old age, diseases, etc. The second equation expresses the principle of conservation of matter within a compartment:

\section{Consumption $=$ production + respiration + unassimilated food}

The formal expressions of the above equations can be written as follows for a group $i$ and its predators $j$ :

$$
\begin{gathered}
B_{i} \times(P / B)_{i}=Y_{i}+\Sigma_{j}\left(B_{j} \times(Q / B)_{j} \times D C_{i j}\right)+E x_{i}+B a C C_{i}+ \\
B_{i}\left(1-E E_{i}\right) \times(P / B)_{i}
\end{gathered}
$$

and

$$
B_{i} \times(Q / B)_{i}=B_{i} \times(P / B)_{i}+R_{i}+U_{i}
$$

where the main input parameters are the biomass $(B)$, the production rate $(P / B)$, the consumption rate $(Q / B)$, the proportion of $i$ in the diet of $j\left(D C_{i j i} D C=\operatorname{diet}\right.$ composition), the net migration rate $(E x)$, the biomass accumulation rate $(B a c c)$, the total catch $(Y)$, respiration $(R)$, the unassimilated food rate $(U)$ and the ecotrophic efficiency $(E E)$. There are as many linear equations as there are groups in the system, so if one of the parameters is unknown for a group, the model computes it by solving the set of linear equations. In particular, $E E$, which corresponds to the fraction of the production of each group that is used in the food web, is difficult both to measure and to estimate. It was left to be estimated by the model for most of the groups.

Constructing and balancing the model: The system described in this study is the marine part of the Gironde estuary between Meschers and Ambès (Fig. 1) at the annual scale. Its surface area is $450 \mathrm{~km}^{2}$ at high tide with an intertidal zone covering about $180 \mathrm{~km}^{2}$. Salinity ranges between 1 and 7 in the upstream part, and between 15 and 30 near the ocean. Mean monthly flow values range between 1470 and $1590 \mathrm{~m}^{3} \mathrm{~s}^{-1}$ in January and February, and $324 \mathrm{~m}^{3} \mathrm{~s}^{-1}$ in August. A preliminary structure of the trophic network and model included 18 biological compartments (Table 1) and 2 anthropogenic compartments (fisheries and industrial pumping). For each compartment, only main species were taken into account and, except for the suprabenthos, only species for which biomass and/or catch data were available were considered in the analysis. Other parameters were estimated using data from literature, other models, empirical relationships and 'guesstimations.' Salmon, lampreys, shads and sea trout were excluded a priori from the model because they were considered not to feed in the estuary or because they do not stay in the estuary for a sufficient time to interact with other stocks.

CIs were included in the Ecoranger routine of the Ecopath with Ecosim software to deal with uncertainty regarding parameter inputs. Data ranges were then computed for each parameter and a sampling/resampling process was repeated in a Monte-Carlo fashion using triangular distribution around the prior until the model fitted with physiological and mass-balance constraints. In particular, in the present model, the minimum and maximum for $P / B$ and $Q / B$ parameters were selected from the literature (Christensen \& Pauly 1993, Ainsworth et al. 2001, Rybarczyk \& Elkaim 2003, Rybarczyk et al. 2003). An SD of $\pm 20 \%$ around the previously chosen values was accepted for the biomass values of primary producers, copepods, mysids, meiobenthos and macrobenthos and all DCs and captures. Minimum and maximum values for fish and shrimp biomass were calculated using fisheries data and an empirical estimation of the exploitation rate for each species. Biomass was expressed in carbon weight $(\mathrm{kgC}$ $\mathrm{km}^{-2} \mathrm{yr}^{-1}$ ) using conversion factors from the literature. Rates are given on an annual basis.

Fisheries and industial impingement: Fisheries data were originally from annual fishery monitoring reports of Cemagref. Fish and shrimp mortalities due to the Braud et Saint-Louis nuclear power plant (CNPE) cooling-water intake were included in the model as a means of indicating impingement equivalent to a removal of fish and shrimp biomass from the system. Mortality data for the main impacted species are from Boigontier \& Mounié (1984).

Fish and shrimps: A preliminary classification procedure (not presented in this paper) based on ecological and trophic guilds, length class and vertical distribution (see Lobry et al. 2003) was made in order to group fish species. Fish and shrimp biomass data were mainly estimated using an empirical exploitation rate $(Y / B)$ of 0.1 for commercial species and a mortality rate of 0.1 for species impacted by CNPE. These rates were used as initial values for the sampling/resampling procedure and the confidence interval was set between 0.1 and 0.8 , which seem to be fairly reasonable values for exploitation of juvenile fish stocks. For species that are neither commercial, nor impacted by pumping, relative abundances with respect to bass Dicentrarchus labrax were calculated using local surveys (Lobry et al. 2003). Consumption rates $(Q / B)$ for each species were estimated using the Palomares and Pauly's empirical relationship (Palomares \& Pauly 1999). The produc- 
Table 1. The 18 biological compartments included in the Ecopath model. Bold: species/groups representing $>30 \%$ of biomass for each compartment

\begin{tabular}{|c|c|c|}
\hline Compartments & Description & Main species/groups \\
\hline Primary producers & $\begin{array}{l}\text { All primary producers of the ecosystem: } \\
\text { phytoplankton and microphytobenthos }\end{array}$ & - \\
\hline Copepods & & Eurytemora affinis, Acartia bifilosa and A. tonsa \\
\hline Suprabenthos & Vagile macrofaunal crustaceans (excepted mysids) & Ex. Gammarus sp. \\
\hline Mysids & Suprabenthic crustaceans & Neomysis integer, Mesopodopsis slabberi \\
\hline Meiobenthos & $\begin{array}{l}\text { Benthic organisms with individual length } \\
<1 \mathrm{~mm} \text {; separated with a } 0.063 \mathrm{~mm} \text { sieve }\end{array}$ & $\begin{array}{l}\text { Nematods, copepods, nauplii, polychaetes, } \\
\text { oligochaetes and others }(<2 \%)\end{array}$ \\
\hline Macrobenthos & $\begin{array}{l}\text { Benthic organisms with individual length } \\
>1 \mathrm{~mm} \text {; separated with a } 1 \mathrm{~mm} \text { sieve }\end{array}$ & $\begin{array}{l}\text { Annelids, molluscs, crustaceans }+ \text { insects (e.g. } \\
\text { Nereis diversicolor, Heteromastus filiformis, } \\
\text { Macoma baltica, Corophium volutator ...) }\end{array}$ \\
\hline Shrimps & & $\begin{array}{l}\text { White shrimp Palaemon longirostris and } \\
\text { brown shrimp Crangon crangon }\end{array}$ \\
\hline Sturgeon & & European sturgeon Acipenser sturio \\
\hline Eel & & European eel Anguilla anguilla \\
\hline Small pelagics & Diadromous or marine pelagic species & $\begin{array}{l}\text { Anchovy Engraulis encrasicolus, smelt } \\
\text { Osmerus eperlanus, sprat Sprattus sprattus }\end{array}$ \\
\hline Mullets & & $\begin{array}{l}\text { Thin lipped grey mullet Liza ramada and } \\
\text { golden grey mullet Liza auratus }\end{array}$ \\
\hline Marine pred. & Euryhaline marine species, mainly predators & $\begin{array}{l}\text { Bass Dicentrarchus labrax, meagre Argyroso- } \\
\text { mus regius }\end{array}$ \\
\hline Large pelagics & Very rare in the Gironde estuary & $\begin{array}{l}\text { White seabream Diplodus sargus, black } \\
\text { seabream Spondyliosoma cantharus }\end{array}$ \\
\hline Pipefish & Marine fish & Nilson's pipefish \\
\hline Flatfish & Marine or diadromous fish & $\begin{array}{l}\text { Flounder Platichtys flesus, soles Solea spp., } \\
\text { raies Raja spp. }\end{array}$ \\
\hline Gobies & Resident species in the Gironde estuary & Pomatoschistus spp. \\
\hline Freshwater fish & Rare in the Gironde estuary & $\begin{array}{l}\text { Barbel Barbus barbus, three-spined stickleback } \\
\text { Gasterosteus aculeatus aculeatus }\end{array}$ \\
\hline Detritus/discards & $\begin{array}{l}\text { Marine and terrestrial particulate organic matter, } \\
\text { dead organisms, faeces and pseudo faeces }\end{array}$ & - \\
\hline
\end{tabular}

tion:biomass ratio $(P / B)$ was assumed to equal total mortality $(Z)$. In particular, for commercial species, $Z$ is the sum of natural mortality $(M)$ and fishing mortality $(F) . M$ was calculated using a re-estimated version of Pauly's relationship (Pauly 1980). Z was calculated using Hoenig's formula (Hoenig 1983). The diet matrices of fish species were mainly constructed using data from local studies and found on Fishbase (www.fishbase. org) and shrimp $P / B$ and $Q / B$ values are from the Ecopath model of the Bay of Biscay (Ainsworth et al. 2001). Due to a lack of data, crabs were not explicitly included in the analysis. Shrimps are thus the only macrocrustacean compartment in the model.

Benthos: Data for benthic invertebrates were obtained from the results of local intertidal (Bachelet 1985, Heip \& Herman 1995) and subtidal (Brosse 2003) benthic faunal studies. The unassimilated food:consumption ratio $(U / Q)$ was set to 0.4 as these species are mostly deposit feeders (Christensen et al. 2000).

Copepods: Copepods' biomass and production data were given by Irigoien (1994) for Acartia spp. and by Feurtet (1989) for Eurytemora spp. The $Q / B$ value was from Kiorboe et al. (1985) for A. tonsa and from Barthel (1983) for E. affinis. Diet compositions of all copepods were obtained from Gasparini \& Castel (1999). U/Q was set to 0.4 as these species are mostly herbivorous and detritivorous (Christensen et al. 2000).

Suprabenthos: Gammarids and suprabenthic isopods and amphipods were aggregated into one compartment. The abundance of these particular groups is probably high in the Gironde estuary (Cemagref, unpubl. data), although very qualitative works (Sorbe 1981) do not give quantitative description and abundance data. $P / B, Q / B$ and $D C$ were estimated using selected values from literature (Christensen \& Pauly 1993, Ainsworth et al. 2001). EE was arbitrarily fixed to 0.8 and the model hence estimated the biomass value that is expected to be a minimum.

Mysids: Biomass values for mysids were estimated using sampling data from the Laboratoire d'Océanographie Biologique (David et al. 2005). Production and consumption rates were found in literature (Mees et al. 1995, Froneman 2001). DCs were deduced from Froneman (2001) and David et al. (2006). 
Primary producers: As it is difficult to separate the part of primary production due to phytoplankton and the part due to resuspension of microphytobenthos (Castel 1993), the 2 groups were aggregated in one compartment. Chlorophyll biomass was used as an indicator of phytoplankton/resuspended microphytobenthic biomass (Lemaire et al. 2002).

Detrital organic matter: The Detritus compartment reflects the standing stock of organic matter in the sediments, the suspended organic matter, inputs from the river basin and from the ocean, flows from living organisms and discards from the fishery and the nuclear power plant. Discards were calculated using fishery and CNPE data, and flows from living organisms are an output of the model. Other contributions to the biomass of the compartment were estimated based on Mauvais \& Guillaud (1994).

Trophic structure and network analysis. The trophic flows were described using 2 graphical representations. The first shows the main trophic interactions in the system and the second shows the distribution of flows along trophic levels using the flow pyramid (Christensen et al. 2000).

Furthermore, we calculated several indices derived from Network Analysis (see Christensen et al. 2000 for details on formulas). By considering some compartment properties (trophic level, TL) and topological indices such as transfer efficiencies (TE), omnivory index (OI) and connectance index (CI), we developed quantitative descriptions of the trophic structure of the ecosystem. These characteristics can be related, to some extent, to the complexity and stability of the system (see for instance Dunne 2006, Martinez et al. 2006 for an historical review of this debate). Both direct and indirect trophic interactions were assessed using the mixed trophic impacts (MTI) approach, which allows for the consideration of the total impacts of fisheries and power plant industrial pumping on the whole ecosystem. In other respects, some system characteristics (total system throughput [TST], ascendancy [A], internal relative ascendancy [Ai/Ci], Finn's cycling index [FCI]) were computed in order to describe the ecological status and functioning of the system, which can essentially be related to Odum's concept of maturity (Odum 1969, Christensen 1995).

\section{RESULTS}

\section{Adequacy of the data and balancing procedure}

Once all inputs and CIs were computed, a step-bystep pragmatic approach was used to balance the model. After each failure in the balancing procedure of the Ecoranger routine, we fixed input parameter values for compartments with estimated $E E<1$ and allowed a new sampling/resampling procedure for the others. This iterative process was repeated 3 times until we obtained a balanced model. However, a marginal adjustment in the confidence interval of the $B$ value of Copepods was necessary and a SD of $\pm 30 \%$ around the previously chosen values was accepted.

Most of the data included in the analysis were collected between 1994 and 2000. Hence, the model is assumed to describe a situation of the late 1990s/early 2000s.

\section{Basic estimates, graphical representations and trophic interactions}

Basic inputs, model estimations for $E E$ and $D C$ of each compartment are given in Tables $2 \& 3$. These values resulted from the sampling/resampling procedure that resulted in a mass-balanced model. Except for Copepods, all the parameter values estimated by the Ecoranger routine were within the CIs selected $a$ priori. The fitting process led to a higher production value for that group compared to the initial expected value. The flows and EE showed a wide range of values indicating that the trophic roles of the different compartments were not equal.

The 2 snapshots (Figs. $2 \& 3$ ) of the organisation of flows in the system clearly show that most of the flows are concentrated at the basis of the trophic networks. The value of the overall transfer efficiency is $7.5 \%$ between trophic levels II and VI, which is relatively low compared to the theoretical value of $10 \%$. As shown by the relative volume of the 2 first stages of the pyramid, there is a breakdown in the transfer efficiency between primary consumers, essentially copepods and mysids (trophic levels II and III) and upper predators such as shrimps or fish (trophic levels III and IV). Eighty-eight percent of the flows at the first trophic level are due to the Detritus compartment but only $15 \%$ of flows due to Detritus are used in the food web $\left(E E_{\text {Detritus }}=0.15\right)$.

The mixed trophic impacts between compartments in the system (Fig. 4) underline the positive impacts of the Detritus compartment on all the other trophic groups of the model. It also highlights the direct negative influences, and the indirect positive and indirect negative influences of the 2 anthropic compartments on most of the living groups of the system at all the trophic levels. The total impacts of the fishery (1.23) and of the industrial pumping by the power plant (0.84) are, respectively, the first and third most important amongst all the ecosystem compartments (see $\varepsilon_{\mathrm{i}}$, Table 2). Although they are of comparable (high) 
Table 2. Basic parameters of the trophic model. TL: Trophic Level, B: Biomass, $Y$ : Catch, $P / B$ : production rate, $Q / B$ : consumption rate, EE: Ecotrophic efficiency, $P / Q$ : Gross efficiency of food conversion, $U / Q$ : unassimilated food ratio, $\varepsilon_{i}$ : total impact on the ecosystem. Italics: parameters estimated by the model

\begin{tabular}{|c|c|c|c|c|c|c|c|c|c|c|}
\hline Compartments & $\mathrm{TL}$ & $B$ & $Y$ & $P / B$ & $Q / B$ & $E E$ & $P / Q$ & $U / Q$ & Imports & $\varepsilon_{\mathrm{i}}$ \\
\hline Primary producers & 1 & 226.6 & & 200.9 & - & 0.83 & - & - & - & 0.66 \\
\hline Copepods & 2 & 460.9 & & 35.9 & 101.8 & 0.94 & 0.35 & 0.40 & - & 0.55 \\
\hline Suprabenthos & 2.03 & 94.8 & & 2.5 & 20.0 & 0.80 & 0.13 & 0.40 & & 0.33 \\
\hline Mysids & 2.56 & 289.3 & & 9.9 & 92.8 & 0.06 & 0.11 & 0.20 & - & 0.75 \\
\hline Meiobenthos & 2.12 & 176.7 & & 10.0 & 21.8 & 0.47 & 0.46 & 0.40 & - & 0.19 \\
\hline Macrobenthos & 2.04 & 730.5 & & 4.3 & 32.6 & 0.18 & 0.13 & 0.40 & - & 0.78 \\
\hline Shrimps & 2.67 & 41.5 & 5996 & 6.5 & 15.7 & 0.79 & 0.42 & 0.20 & - & 0.62 \\
\hline Sturgeon & 3.2 & 1.0 & & 0.1 & 3.3 & 0.00 & 0.02 & 0.20 & - & 0.01 \\
\hline Eel & 3.55 & 2.2 & 1754 & 1.0 & 6.3 & 0.80 & 0.16 & 0.20 & - & 0.81 \\
\hline Small pelagics & 3.08 & 6.8 & 3620 & 3.8 & 17.7 & 0.60 & 0.21 & 0.20 & - & 0.27 \\
\hline Mullets & 2.3 & 23.8 & 4777 & 3.5 & 7.5 & 0.13 & 0.46 & 0.20 & - & 0.25 \\
\hline Large marine fishes & 3.68 & 20.9 & 8890 & 2.0 & 4.1 & 0.21 & 0.50 & 0.20 & - & 0.87 \\
\hline Large pelagics & 3.21 & 0.0 & & 0.9 & 7.3 & 0.00 & 0.13 & 0.20 & - & 0.00 \\
\hline Pipefish & 3.03 & 1.9 & 0910 & 1.3 & 8.3 & 0.77 & 0.15 & 0.20 & - & 0.04 \\
\hline Flatfish & 3.28 & 5.7 & 0593 & 1.7 & 5.3 & 0.77 & 0.32 & 0.20 & - & 0.07 \\
\hline Gobies & 3.25 & 33.1 & 4590 & 1.6 & 12.8 & 0.33 & 0.12 & 0.20 & - & 0.71 \\
\hline Freshwater fish & 3.21 & 0.2 & & 0.6 & 4.8 & 0.92 & 0.13 & 0.20 & - & 0.01 \\
\hline Detritus/discards & 1 & 188667 & & - & - & 0.15 & - & - & 272222 & - \\
\hline
\end{tabular}

Table 3. Predator/prey matrix. The fraction of one compartment consumed by another is expressed as a fraction of the total diet

\begin{tabular}{|c|c|c|c|c|c|c|c|c|c|c|c|c|c|c|c|c|c|}
\hline & Prey/Predator & 2 & 3 & 4 & 5 & 6 & 7 & 8 & 9 & 10 & 11 & 12 & 13 & 14 & 15 & 16 & 17 \\
\hline 1 & Primary producers & 0.36 & 0.40 & 0.31 & 0.22 & 0.46 & 0.17 & & & & 0.14 & & & & & & \\
\hline 2 & Copepods & & & 0.56 & & & 0.23 & & & 0.47 & 0.17 & & & 0.72 & & 0.32 & \\
\hline 3 & Suprabenthos & & & & & & & & & 0.31 & & 0.13 & & & 0.19 & 0.32 & \\
\hline 4 & Mysids & & 0.02 & & & & 0.17 & 0.13 & 0.01 & 0.08 & & 0.02 & & & 0.00 & 0.06 & 0.01 \\
\hline 5 & Meiobenthos & & & & 0.11 & 0.02 & & & & 0.01 & 0.03 & & & 0.28 & & & \\
\hline 6 & Macrobenthos & & & & & 0.02 & 0.17 & 0.77 & 0.27 & 0.03 & 0.09 & & 0.81 & & 0.42 & & 0.77 \\
\hline 7 & Shrimps & & & & & & 0.01 & 0.06 & 0.59 & 0.06 & & 0.55 & 0.10 & & 0.39 & 0.30 & 0.17 \\
\hline 8 & Sturgeon & & & & & & & & & & & & & & & & \\
\hline 9 & Eel & & & & & & & & & & & & & & & & \\
\hline 10 & Small pelagics & & & & & & & & 0.01 & 0.01 & & 0.08 & 0.02 & & & & 0.01 \\
\hline 11 & Mullets & & & & & & & & & & & 0.07 & & & & & \\
\hline 12 & Marine predators & & & & & & & & & & & & & & & & \\
\hline 13 & Large pelagics & & & & & & & & & & & & & & & & \\
\hline 14 & Pipefish & & & & & & & & & & & & & & & & \\
\hline 15 & Flatfish & & & & & & & & 0.05 & & & 0.07 & & & & & \\
\hline 16 & Gobies & & & & & & & 0.05 & 0.05 & & & 0.08 & 0.07 & & 0.00 & & 0.03 \\
\hline \multirow[t]{3}{*}{17} & Freshwater fish & & & & & & & & 0.01 & & & & & & & & 0.01 \\
\hline & Detritus/discards & 0.64 & 0.58 & 0.13 & 0.67 & 0.51 & 0.27 & & 0.01 & 0.03 & 0.57 & & & & 0.00 & & \\
\hline & Total & 1.00 & 1.00 & 1.00 & 1.00 & 1.00 & 1.00 & 1.00 & 1.00 & 1.00 & 1.00 & 1.00 & 1.00 & 1.00 & 1.00 & & 1.00 \\
\hline
\end{tabular}

importance, these impacts are not directed towards the same components of the food web. The fishery mainly impacts top predators of the ecosystem, such as Eel and Large Marine Fish (meagre and bass), whereas impingement mainly impacts Pipefish and intermediate trophic levels (Gobies, Small pelagics, Suprabenthos and Shrimps).

\section{System characteristics}

The main Gironde estuarine system indices (Table 4) are distinguishable from the values for the Seine estuary (Rybarczyk \& Elkaim 2003), the Bay of Somme
(Rybarczyk et al. 2003) and other European, American and African systems-Ems and Swartkops (Baird \& Ulanowicz 1993), Dublin Bay (Wilson \& Parkes 1998), Nagarransett, Delaware and Chesapeake bays (Monaco \& Ulanowicz 1997) - by relatively low values of TST, CI, A, Ai/Ci and FCI, intermediate value of OI and high value of relative ascendancy (A/C). In addition, indicative values or levels for a hypothetic mature ecosystem are proposed. Levels (high or low) are from Christensen (1995) and derived from Odum's theory on ecosystem's maturity (Odum 1969) and the quantitative values were compiled from the literature (Baird \& Ulanowicz 1993, Christensen \& Pauly 1993, Christensen 1995, Monaco \& Ulanowicz 1997). 


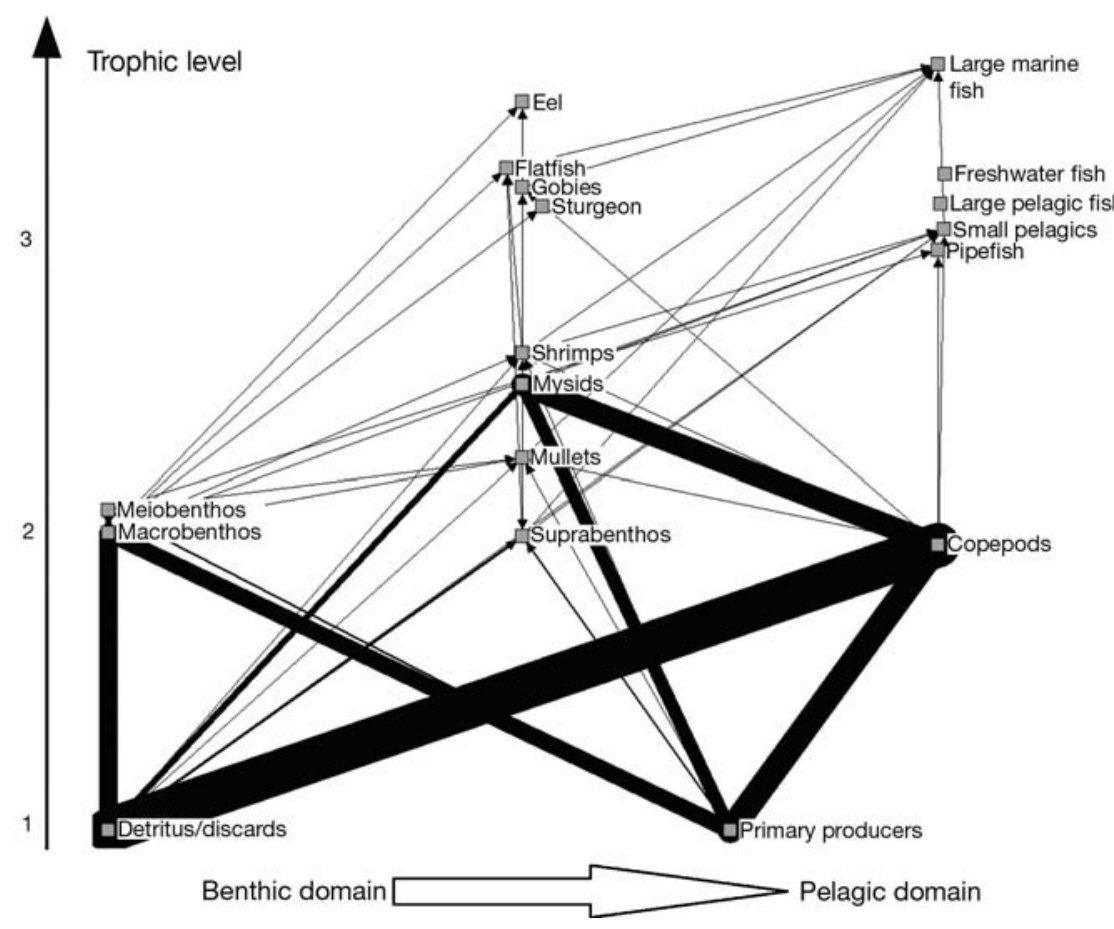

Fig. 2. Gironde estuarine food web. Only the most important flows (arrows) and compartments (boxes) are presented (>90\% of total flow value and $70 \%$ of total interactions). The width of each arrow is scaled to the trophic flow value

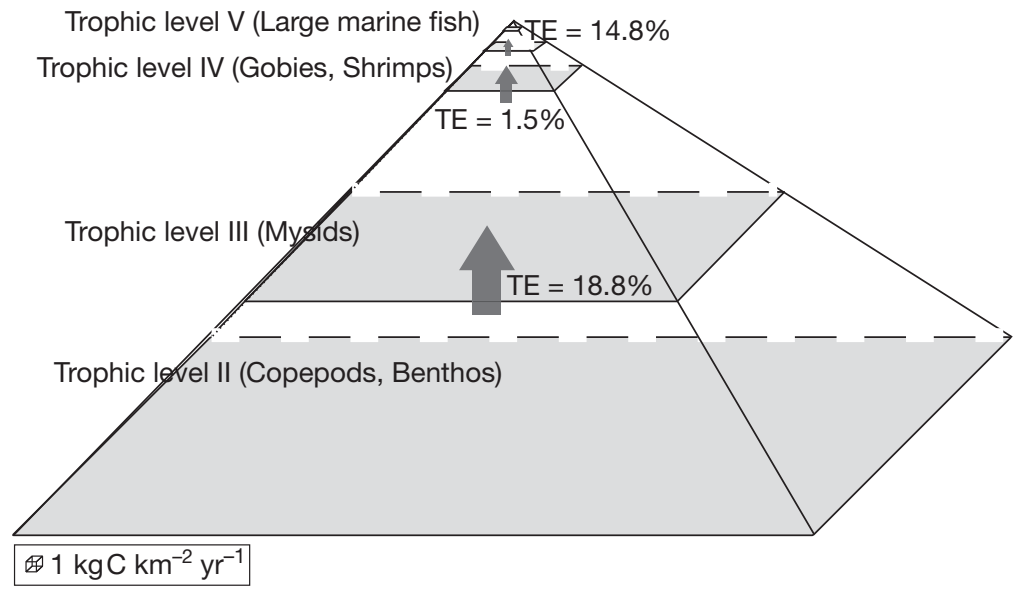

Fig. 3. Gironde estuarine food web. Main species (in terms of flow values) and transfer efficiencies are indicated for each discrete trophic level

derestimated due to a lack of data on microphytobenthic production in intertidal areas; however, the low production may be caused by the high turbidity of the estuarine water. The Gironde is one of the most turbid estuaries in Europe (Sautour \& Castel 1995) and the waters of the Seine estuary (Rybarczyk \& Elkaim 2003) — and even those of the Bay of Somme (Rybarczyk et al. 2003) are more translucent and more favourable to phytoplankton development. This low value of primary production reflects the low value of the Gironde's TST, which is on the same order of magnitude as that of the Ems estuary (Baird \& Ulanowicz 1993) or of Dublin bay (Wilson \& Parkes 1998), but 5 times lower than the Seine's TST. This implies no pronounced phytoplanktonic bloom, but constant seasonal high concentrations of allochthonous matter (Sintes et al. 2004). As a consequence, the trophic organisation of the Gironde appears to be strongly detritus based; $88 \%$ of the total flows in the system come from the Detritus compartment. The terrestrial and riverine POM inputs are thus particularly important in the Gironde estuary (>270000 $\mathrm{kgC} \mathrm{km}^{-2} \mathrm{yr}^{-1}$ ) and constitute major sources of organic matter in the system, making the Gironde estuary not only a detritus-based food web, but also a typical heterotrophic ecosystem (features it shares with many typical temperate estuaries - see McLusky \& Elliott 2004). In addition, this high dependency on external connections (Baird et al. 1991), and particularly on detritus inputs, is suggested by the great difference between the values of the $\mathrm{A} / \mathrm{C}(48 \%)$ and the $\mathrm{Ai} / \mathrm{Ci}(17 \%)$ ratios, coupled with the relatively low level of recycling of energy (FCI = $13 \%)$. This probably means that because the supply of organic matter is

\section{DISCUSSION}

\section{Topological patterns in the Gironde estuarine trophic network}

One of our most important findings is that the Gironde is characterised by a very low primary production - 19 times lower than in the Seine estuary (Rybarczyk \& Elkaim 2003). This flow is probably un- much larger than the demand, the system does not need to develop a costly mechanism to cycle energy. Consequently, the rich and abundant microbiota associated with detritus plays an important role in the transfer of detrital energy to the food web, in particular via zooplankton (Heinle et al. 1977). Copepods, which are expected to be a major trophic node between POM and consumers, exert a rather low grazing pressure on vegetal POM (19\% d ${ }^{-1}$; David et al. 2006), probably due 


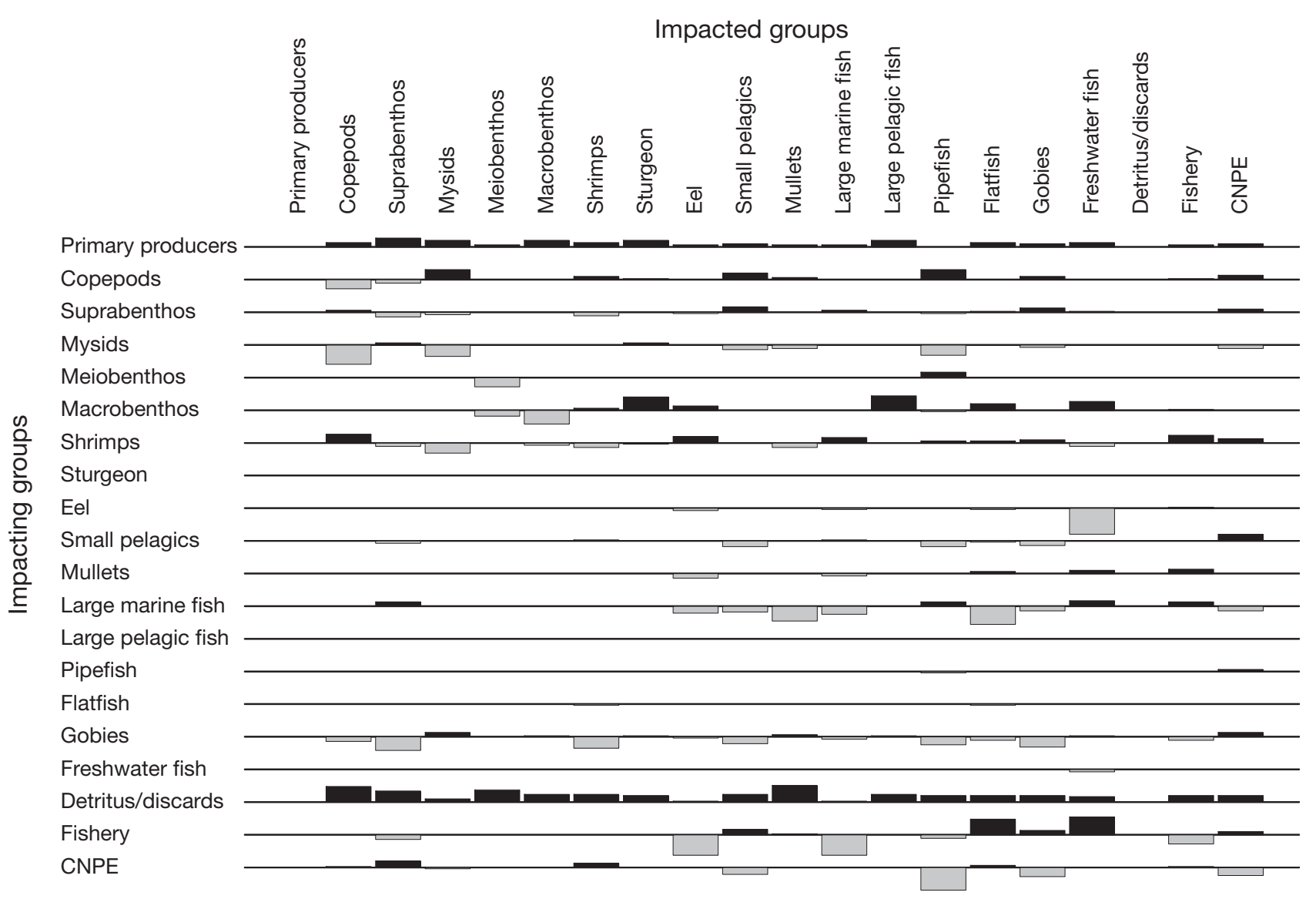

Fig. 4. Combined direct and indirect trophic impacts. Bars pointing upwards (black) indicate positive impacts, while the bars pointing downwards (grey) show negative impacts. Bars should not be interpreted in an absolute sense: impacts are relative, but comparable between groups. CNPE: Centre Nucléaire de Production d'Electricité de Braud et Saint-Louis (Braud et Saint-Louis nuclear power plant)

to high contribution of detrital matter to vegetal POM and the low quality of this food source (Heinle et al. 1977). Furthermore, most of the trophic groups of our model, including large species (such as sturgeon) and marine predators, are also able to feed on the lowest trophic levels, leading to non-linear food chains and a compactness of the food web. That feature results partially from the fact that most of the considered fishes are juveniles that use the estuary as nursery grounds.

The above elements are associated with low transfer efficiencies. In particular, the available organic matter seems not limiting, but globally underexploited $\left(E E_{\text {detritus }}=0.15\right)$. The detritus food chain results in important carbon losses through the multiplicity of the trophic transfers (no direct consumption of detritus by zooplankton, more probably a 2- or 3-stage route; Heinle et al. 1977). So, as shown by the graphic representations of the trophic network, most of the biomass and production are contained within lower trophic levels. In particular, the fraction of energy produced by benthic infauna that is used in the food web is rela- tively low (around $31 \%$ if meiobenthos and macrobenthos were aggregated), reflecting that benthos is underexploited in the Gironde food web in comparison with similar systems. In parallel, the relationship between copepods, mysids and fish appears to be a key pathway. In estuarine ecosystems, zooplankton is considered to be the basis of the pelagic trophic web, linking the riverine input and the exploited macrofauna (Mees et al. 1995, Gasparini \& Castel 1999, David et al. 2005). Copepods are subjected to an intense predation pressure, especially by mysids, which do not transfer carbon efficiently to higher trophic levels (<7\%). As a consequence, the model predicts an intense competition for copepods, which are the most important vector for carbon transfer from detritus to top predators (Tackx et al. 2003). This can be partly linked to a low global omnivory $(\mathrm{OI}=0.12)$, and more generally, to the relatively low complexity of the network structure suggested by the low connectance of the trophic compartments $(\mathrm{CI}=0.27)$, which reinforces concentration of the trophic flows at the lower levels of the food web. 


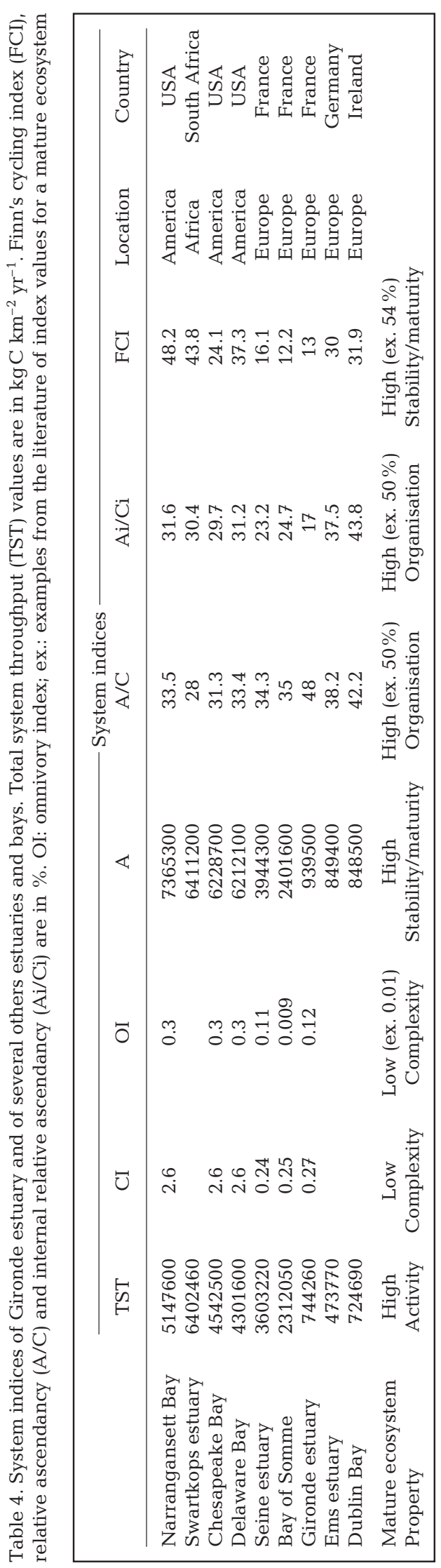

\section{Maturity and stability of the system}

The detritus-based organisation and the poor transfer efficiency towards higher trophic levels are associated with a low global complexity and a high dependence on external connections. These characteristics could suggest the system is far from a stable mature ecosystem sensu Odum (1969) (see Ulanowicz 2003). It is also different from other similar systems, such as the Seine, the Somme and the American bays. However, most marine systems are characterised by a mixture of features common among both mature systems and those under development (Baird et al. 1991, Elliott \& Quintino 2007). This observation seems especially true in transitional waters such as estuaries (Baird \& Ulanowicz 1993, Rybarczyk \& Elkaim 2003) and bays (Monaco \& Ulanowicz 1997, Wilson \& Parkes 1998, Rybarczyk et al. 2003).

All the estuarine-like systems are typically characterised by large-scale fluctuations in the physicochemical conditions at various spatial (e.g. upstreamdownstream salinity gradient, vertical turbidity gradient, lateral Coriolis-induced) and temporal (from tidal to interannual) scales (McLusky 1981). In some way, this hydrological stress can be compared to the physical stress of upwelling ecosystems, in the sense that it is cyclical, preventing the development of a complex organisation of the trophic network, but allows the system to remain very productive at the global level and to support, in particular, important fish stocks. Estuarine systems, just like upwellings, are constrained by these cyclical perturbations and in particular by the seasonal fluctuations of the river flow, the water temperature, the water salinity and turbidity. The system's stability is based on its capacity to cope with those naturally variable conditions.

Although the Gironde is immature and perturbed, the $\mathrm{A} / \mathrm{C}$ and $\mathrm{Ai} / \mathrm{Ci}$ ratios suggest that it is quite stable with an intermediate-to-high level of organisation $(\mathrm{A} / \mathrm{C}=48 \%)$. This, coupled with the system overhead, will give a useful measure of the stability of the system. The high overhead of the network reflects a high proportion of parallel pathways in the system (Allesina et al. 2005) and the combination of pathways provides an important stabilising effect in the trophic relationships within the estuarine detritus food chain (Fenchel 1972). Hence, a system can be stable even if it is not yet in an ecological climax state. Most notably, the detritus food web smooths the seasonal production of organic matter and acts as a store of energy by fixing the energy seasonally through grazing of primary producers over a longer time (Riley 1963), and so adds stability to the ecosystem. Avoiding seasonal perturbations depends largely on this parameter. It also largely depends on the existence of distinct asymmetrical energy channels 
(one based on primary production and another, more importantly, based on POM inputs) and the mobile higher-order consumers that couple them (Dunne et al. 2005, Martinez et al. 2006, Rooney et al. 2006).

These features indicate a kind of paradox in that the lower the system's ascendancy, the higher its overhead, its ability to respond favourably to perturbations (see Elliott \& Quintino 2007) - in other words, its resilience. Finally, despite potentially acute hydrologic and anthropogenic stress, the system is able to optimise the use of available trophic resources. The complexity in the trophic organisation remains limited and its success is mainly due to the interannual constancy of the trophic structure. As a consequence, the maturity of the system, in cases of ecosystems submitted to intense cyclical perturbations of the environment, probably should not be understood in Odum's sense, but rather in terms of potential level of organisation. This is called the 'biodiversity-ecosystem-functioning debate' (see Elliott et al. 2007, Elliott \& Quintino 2007), wherein marine and freshwater systems are regarded as having a higher biodiversity, which is regarded as necessary for good ecosystem function. However, in estuaries, the debate is whether a low biodiversity is necessary for good ecosystem functioning - hence the paradox discussed by Elliott \& Quintino (2007).

\section{Seasonal patterns}

Three main ecological seasons, corresponding to 2 very distinctive fish and shrimp assemblages, and one transitional assemblage, have been described in the Gironde estuary (Lobry et al. 2006). In particular, cold months (approximately from November to March) can be associated with estuarine benthic and demersal species (e.g. glass eel, mullets, gobies, flounder, shrimps) whereas warm months (approximately from July to October) are associated with pelagic species (e.g. bass, shads, anchovy, sprat) entering the estuary from the coastal zone. These 'summer' species are mostly zooplankton feeders, whereas 'winter' fish and shrimp species feed more on benthic resources. A kind of flow transfer in the water column thus occurs when the organic matter inputs decrease, in close correlation with the value of the river flow (Fig. 5).

Two different trophic channels are probably developed during these 2 seasons: one leading to the top of the food chain starting from detritus and passing through benthos and suprabenthos, and one starting from detritus and primary producers via mysids and copepods (see Elliott \& Hemingway 2002 for details). As suggested by the EE values, the Benthos and Suprabenthos compartments are probably not limiting due to density values that are relatively high throughout the year. This allows benthic species (e.g. sole, flounder, eel), which are omnivorous, to feed on benthic invertebrates even during winter. Conversely, the seasonal dynamics of zooplankton is more noticeable. High densities in spring and autumn, in particular since 1999 (David et al. 2007), make the estuary suitable for marine pelagic secondary consumers such as clupeids during this season and allow the development of a pelagic food chain.

\section{Management issues}

Historical evidence shows that structure and species composition of estuarine communities in general are not persistent in a strictly quantitative view. In the Gironde area, the colonisation of non-indigenous species (Acartia tonsa, David et al. 2007) and the important decrease in abundance of charismatic species such as the European sturgeon Acipenser sturio (Lepage \& Rochard 1995) or smelt Osmerus eperlanus (Pronier \& Rochard 1998) are notable examples of deep impacts on biological communities by large natural modifications or anthropogenic disturbances. In the Gironde, the main human-induced impacts are fisheries, damages to estuarine habitats, and thermal and physical impacts (impingement) of the nuclear power

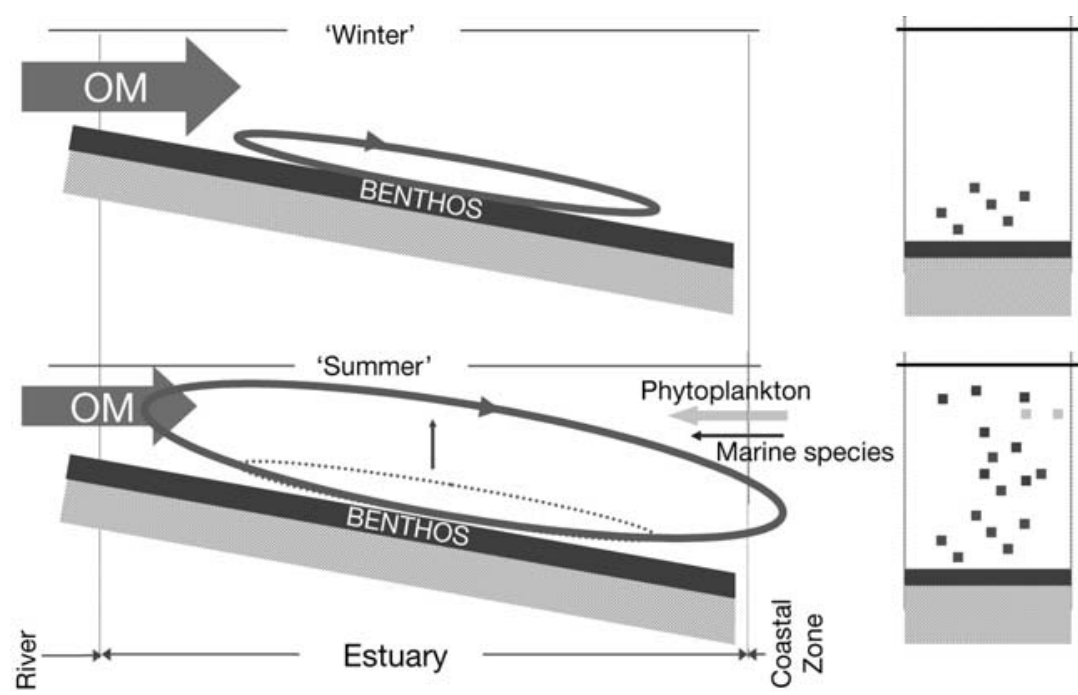

Fig. 5. Assumption of differential distribution of trophic flows (elliptical arrows) in the water column according to season. Width of organic matter (OM) arrows is relative to $\mathrm{OM}$ input from rivers (greater in winter). Righthand panels represent water column 
station. Only fisheries and impingement by the power plant were included in the Ecopath model, allowing the quantification of their net impacts on the biological compartments. Potential consequences of those 2 sources of mortality are not equivalent because they do not impact the same part of the trophic network. On the one hand, exploited fish stocks are top predators that enhance resilience and the use of basal production, whereas the negative impacts of impingement essentially concern key trophic species that play a switching role between the different channels of carbon use. However, in both cases increasing these impacts could deeply affect the topology, status and functioning of the food web by impacting biological groups that have stabilising effects on the network.

Monitoring the response of estuarine ecosystems to those perturbations requires the development of biotic indexes, in the context of the Ecosystem Approach to Fisheries (Garcia et al. 2003), the European Water Framework Directive (EU 2000) or the future European Marine Strategy Directive (EU 2005). From that perspective (see the discussion in Elliott \& Quintino 2007; also de Jonge et al. 2006 on the monitoring in the WFD), our work has showed that, for instance, primary production (and thus phytoplankton biomass and relative indicators) are probably not really appropriate measures for estimating estuarine ecosystem status. On the other hand, the relative abundance of pelagic and benthic species, or of estuarine resident and marine species, could be an indicator of the trophic carrying capacity of the system. The amount of exchange of marine fishes between the estuary and the related coastal zone is probably an indicator of habitat suitability and depends on the occurrence of some prey, such as zooplankton, that allow flow transfer from the first trophic level to the upper part of the food chain.

\section{CONCLUSIONS}

By illustrating potential key patterns in the functioning of estuarine ecosystems through the example of the Gironde estuary, this study shows that estuarine ecosystems have evolved efficient responses to the challenge of environmental instability. One main conclusion of this work is the assumption that in a typical heterotrophic estuary like the Gironde, the asymmetrical distribution of flows between distinct and complementary energy channels (which enhances the stability in the topological pattern of the food web) is a dynamic process illustrated by a differential distribution of the trophic flows in the water column according to the seasons. The use of the available carbon resources over a typical year is optimised by the succes- sion of the species in the environment. The continuing hydrodynamical and hydromorphological variability that maintains the estuary in a non-climax state is the origin of the resilience of the estuarine ecosystem to natural, as well as (most likely) anthropogenic perturbations.

Further research efforts and data are now necessary to determine the extent to which the structure of communities translates into the trophic functioning of the system. This is important for linking observed ecological structures to a sound functional framework if we are to understand the ecosystem's response to perturbations and engage in active management. In this way, we assume that the theoretical and methodological framework employed in this study is an important step toward better linking ecological assemblage structure and ecosystem function in estuarine areas.

Ecosystem theory, like most of the systems it studies, is still under development (Ulanowicz 2003), particularly the biodiversity-ecosystem functioning debate for estuaries (Elliott \& Quintino 2007). While many assumptions used in the modelling here are open to question, given their derivation from other systems, we consider the overall direction of the conclusions to be valid. It is likely that new measurements of biomass, primary production and diet in the Gironde estuary will soon modify (to a greater or lesser extent) the modelling used here; however, the assumptions we have formulated and the questions we have asked can be applied generally as main points for a central theory of the stability of estuarine ecosystems.

Acknowledgements. The authors are grateful to all the participants in the Ecopath workshops held in Cemagref Bordeaux on 24 and 25 September 2001-particularly to P. Chardy (Université Bordeaux I) for his helpful advice on ecosystem approach and to P. Elie (Cemagref Bordeaux) for experienced comments on estuarine ecology. We also thank G. Bachelet (Université Bordeaux I) for data on benthos and M. Girardin (Cemagref Bordeaux) for data on the Gironde estuarine fish and shrimps. Finally, we warmly thank M. Elliott, S. Boyes and $E$. Burdon and the 2 anonymous reviewers for their helpful comments about the form and the substance of an earlier version of this manuscript.

\section{LITERATURE CITED}

Ainsworth C, Ferriss F, Leblond E, Guénette S (2001) The Bay of Biscay, France; 1998 and 1970 models. In: Guénette S, Christensen V, Pauly D (eds) Fisheries impacts on North Atlantic ecosystems: models and analyses. The Fisheries Centre, University of British Columbia, Vancouver, p 271-313

Allesina S, Bondavalli C, Scharler UM (2005) The consequences of the aggregation of detritus pools in ecological networks. Ecol Model 189:221-232

Bachelet G (1985) Distribution et structure des communautés benthiques dans l'estuaire de la Gironde. Proc BOR- 
DOMER 1985 Symp, Bordeaux, 8-11 Octobre 1985. Association pour le Développement des Recherches Marine en Aquitane, Bordeaux, p 541-554

Bachelet G, Bouchet JM, Lissalde P (1981) Les peuplements benthiques dans l'estuaire de la Gironde: biomasse, productivité et évolution structurale. Oceanis Ser Doc Oceanogr 6:593-620

Baird D, Ulanowicz RE (1993) Comparative study on the trophic structure, cycling and ecosystem properties of four tidal estuaries. Mar Ecol Prog Ser 99:221-237

Baird D, McGlade JM, Ulanowicz RE (1991) The comparative ecology of six marine ecosystems. Philos Trans R Soc Lond B 333:15-29

Barthel KG (1983) Food uptake and growth efficiency of Eurytemora affinis (Copepoda:Calanoida). Mar Biol 74: 269-274

Boigontier B, Mounié D (1984) Contribution à la connaissance de la dynamique de la macrofaune bentho-démersale et pélagique en Gironde. Tentatives et difficultés pour relativiser l'impact mécanique d'une centrale nucléaire: le Blayais (Gironde). PhD thesis, Ecole Nationale Supérieure Agronomique de Toulouse

Brosse L (2003) Caractérisation des habitats des juvéniles d'esturgeon européen, Acipenser sturio, dans l'estuaire de la Gironde: relations trophiques, hiérarchisation et vulnérabilité des habitats. PhD thesis, Université Paul Sabatier, Toulouse

Castel J (1993) Long-term distribution of zooplankton in the Gironde Estuary and its relation with river flow and suspended matter. Cah Biol Mar 34:145-163

Christensen V (1995) Ecosystem maturity — towards quantification. Ecol Model 77:3-32

Christensen V, Pauly D (1992) ECOPATH II - a software for balancing steady-state ecosystem models and calculating network characteristics. Ecol Model 61:169-185

Christensen V, Pauly D (eds) (1993) Trophic models of aquatic ecosystems. ICLARM, Manilla

Christensen V, Walters C, Pauly D (2000) Ecopath with Ecosim: a user's guide. Fisheries Centre, University of British Columbia, Vancouver

$>$ Dauvin JC (2007) Paradox of estuarine quality: Benthic indicators and indices, consensus or debate for the future. Mar Pollut Bull 55:271-281

David V, Sautour B, Chardy P, Leconte M (2005) Long-term changes of the zooplankton variability in a turbid environment: the Gironde estuary (France). Estuar Coast Shelf Sci 64:171-184

> David V, Sautour B, Galois R, Chardy P (2006) The paradox high zooplankton biomass-low vegetal particulate organic matter in high turbidity zones: what way for energy transfer? J Exp Mar Biol Ecol 333:202-218

> David V, Sautour B, Chardy P (2007) Successful colonization of the calanoid copepod Acartia tonsa in the oligomesohaline area of the Gironde estuary (SW France) natural or anthropogenic forcing? Estuar Coast Shelf Sci 71:429-442

de Jonge VN, Elliott M, Brauer VS (2006) Marine monitoring: its shortcomings and mismatch with the EU water framework directive's objectives. Mar Pollut Bull 53:5-19

Dunne JA (2006) The network structure of food webs. In: Pascual M, Dunne JA (eds) Ecological networks: linking structure to dynamics in food webs. Oxford University Press, New York, p 27-86

Dunne J, Brose U, Williams RJ, Martinez ND (2005) Modeling food-web dynamics: complexity-stability implications. In: Belgrano A, Scharler UM, Dunne J, Ulanowicz RE (eds) Aquatic food webs: an ecosystem approach. Oxford Uni- versity Press, Oxford, p 117-129

Elliott M, Hemingway K (eds) (2002) Fishes in estuaries. Blackwells, London

Elliott M, Quintino V (2007) The estuarine quality paradox: environmental homeostasis and the difficulty of detecting anthropogenic stress in naturally stressed areas. Mar Pollut Bull 54:640-645

Elliott M, Burdon D, Hemingway KL, Apitz SE (2007) Estuarine, coastal and marine ecosystem restoration: confusing management and science - a revision of concepts. Estuar Coast Shelf Sci 74:349-366

EU (2000) Parliament and Council Directive 2000/60/EC of 23rd October 2000. Establishing a framework for community action in the field of water policy. Official Journal PE-CONS 3639/1/00 REV 1, Brussels

EU (2005) Proposal for a Directive of the European Parliament and of the Council, establishing a framework for community action in the field of marine environmental policy, COM (2005), 505 final, SEC (2005), 1290, Brussels

Fenchel T (1972) Aspects of decomposer food chains in marine benthos. Verh Dtsch Zool Ges 65:14-23

Feurtet A (1989) Dynamique de population, caractérisation morphologique et production secondaire d'Eurytemora affinis hirundoides (copépode Calanoide) dans l'estuaire de la Gironde. PhD thesis, Université de Bordeaux I

Froneman PW (2001) Feedind ecology of the mysid, Mesopodopsis wooldridgei, in a temperate estuary along the eastern seabord of South Africa. J Plankton Res 23: 999-1008

Garcia SM, Zerbi A, Aliaume C, Do Chi T, Lasserre G (2003) The ecosystem approach to fisheries. Issues, terminology, principles, institutional foundations, implementation and outlook. Report No. 443, FAO

Gasparini S, Castel J (1997) Autotrophic and heterotrophic nanoplankton in the diet of the estuarine copepods Eurytemora affinis and Acartia bifilosa. J Plankton Res 19: $877-890$

> Goosen NK, Kromkamp J, Peene J, van Rijswik P, van Breugel P (1999) Bacterial and phytoplankton production in the maximum turbidity zone of three European estuaries: the Elbe, Westerschelde and Gironde. J Mar Syst 22:151-171

- Heinle DR, Harris RP, Ustach JF, Flemer DA (1977) Detritus as food for estuarine copepods. Mar Biol 40:341-353

- Heip C, Herman P (1995) Major biological processes in European tidal estuaries: a synthesis of the JEEP-92 Project. Hydrobiologia 311:1-7

Hoenig JM (1983) Empirical use of longevity data to estimate mortality rates. Fish Bull (Wash DC) 82:898-903

Irigoien X (1994) Ingestion et production secondaire des copépodes planctoniques de l'estuaire de la Gironde en relation avec la distribution du phytoplancton et de la matière en suspension. $\mathrm{PhD}$ thesis, Université de Bordeaux I

Irigoien X, Castel J (1997) Light limitation and distribution of chlorophyll pigments in a highly turbid estuary: The Gironde (SW France). Estuar Coast Shelf Sci 44:507-517

Kiorboe T, Mohlenberg F, Hamburger K (1985) Bioenergetics of the planktonic copepod Acartia tonsa: relation between feeding, egg production and respiration, and composition of specific dynamic action. Mar Ecol Prog Ser 26:85-97

Lemaire E, Abril G, De Wit R, Etcheber H (2002) Distribution of phytoplankton pigments in nine European estuaries and implications for an estuarine typology. Biogeochemistry 59:5-23

Lepage M, Rochard E (1995) Threatened fishes of the world: Acipenser sturio Linnaeus, 1758 (Acipenseidae). Environ Biol Fishes 43:28 
Livingston RJ (2002) Trophic organization in coastal systems. CRC Press, Boca Raton, FL

Lobry J, Mourand L, Rochard E, Elie P (2003) Structure of the Gironde estuarine fish assemblages: a European estuaries comparison perspective. Aquat Living Resour 16:47-58

Lobry J, Lepage M, Rochard E (2006) From seasonal patterns to a reference situation in an estuarine environment: example of the small fish and shrimp fauna of the Gironde estuary (SW France). Estuar Coast Shelf Sci 70:239-250

Martinez ND, Williams RJ, Dunne JA (2006) Diversity, complexity, and persistence in large model ecosystems. In: Pascual M, Dunne JA (eds) Ecological networks: linking structure to dynamics in food webs. Oxford University Press, New York, p 163-185

Mauvais JL, Guillaud JF (1994) Livre blanc de l'Estuaire de la Gironde: etat des connaissances sur l'estuaire de la Gironde. IFREMER - Agence de l'eau Adour-Garonne, Toulouse

McLusky DS (1981) The estuarine ecosystem. Wiley, New York

McLusky D, Elliott M (2004) The estuarine ecosystem: ecology, threats and management. Oxford University Press, Oxford

> Mees J, Fockedey N, Hamerlynkck O (1995) Comparative study of the hyperbenthos of three European estuaries. Hydrobiologia 311:153-174 (Historical Archive)

Monaco ME, Ulanowicz RE (1997) Comparative ecosystem trophic structure of three US mid-Atlantic estuaries. Mar Ecol Prog Ser 161:239-254

Odum EP (1969) The strategy of ecosystem development. Science 164:262-270

Palomares MLD, Pauly D (1998) Predicting the food consumption of fish populations as functions of mortality, food type, morphometrics, temperature and salinity. Mar Freshw Res 49:447-453

Pauly D (1980) On the interrelationships between natural mortality, growth parameters, and mean environmental temperature in 175 fish stocks. ICES J Mar Sci 39:175-192

Polovina JJ (1984) Model of a coral reef ecosystem. The Ecopath model and its application to French Frigate Shoals. Coral Reefs 3:1-11

Editorial responsibility: Howard Browman, Storebø, Norway
Pronier O, Rochard E (1998) Fonctionnement d'une population d'éperlan (Osmerus eperlanus, Osmériformes Osmeridae) située en limite méridionale de son aire de répartition, influence de la température. Bull Fr Peche Piscicult 350-51:479-497

Riley GA (1963) Organic aggregates in a sea water and the dynamics of their formation and utilization. Limnol Oceanogr 8:373-381

Rooney N, McCann K, Gellner G, Moore JC (2006) Structural asymmetry and the stability of diverse food webs. Nature 442:265-269

Rybarczyk H, Elkaim B (2003) An analysis of the trophic network of a macrotidal estuary: the Seine Estuary (Eastern Channel, Normandy, France). Estuar Coast Shelf Sci 58: 775-791

Rybarczyk H, Elkaim B, Ochs L, Loquet N (2003) Analysis of the trophic network of a macrotidal ecosystem: the Bay of Somme (Eastern Channel). Estuar Coast Shelf Sci 58: $405-421$

Sautour B, Castel J (1995) Comparative spring distribution of zooplankton in three macrotidal European estuaries. Hydrobiologia 311:139-151

Sintes E, Martinez-Taberner A, Moya G, Ramon G (2004) Dissecting the microbial food web: structure and function in the absence of autotrophs. Aquat Microb Ecol 37:283-293

Sorbe JC (1981) La macrofaune vagile de l'estuaire de la Gironde. Distribution et migration des espèces. Mode de reproduction, régime alimentaire. Oceanis, Doc Oceanogr 6:579-592

Sottolichio A, Castaing P (1999) A synthesis on seasonal dynamics of highly-concentrated structures in the Gironde estuary. CR Acad Sci Ser II Fasc A Sci Terre Planetes 329: 795-800

Tackx MLM, Herman PJM, Gasparini S, Irigoien X, Billiones R, Daro MH (2003) Selective feeding of Eurytemora affinis (Copepoda, Calanoida) in temperate estuaries: model and field observations. Estuar Coast Shelf Sci 56:305-311

Ulanowicz RE (2003) Some steps toward a central theory of ecosystem dynamics. Comput Biol Chem 27:523-530

Wilson JG, Parkes A (1998) Network analysis of the energy flow through the Dublin Bay ecosystem. P Roy Irish Acad B 98B:179-190

Submitted: July 4, 2007; Accepted: October 22, 2007

Proofs received from author(s): April 9, 2008 